\title{
ЕФЕКТИВНІСТЬ ВИКОРИСТАННЯ БУГӒ̈В-ПЛІДНИКІВ, ОЦІНЕНИХ ЗА ЕКСТЕР'ЄРНИМ ТИПОМ ЇХНІХ ДОЧОК, У СТАДІ З РОЗВЕДЕННЯ МОЛОЧНОЇ ХУДОБИ
}

\author{
Хмельничий Леонтій Михайлович \\ доктор сільськогосподарських наук, професор \\ Сумський національний аграрний університет \\ ORCID: 0000-0001-5175-1291 \\ E-mail: khmelnychy@ukr.net \\ Карпенко Богдан Миколайович \\ аспірант, спеціальність 204-ТВППТ \\ Сумський національний аграрний університет \\ ORCID: 0000-0002-9942-5863 \\ E-mail: karpenkobogdan95@gmail.com
}

Проведено дослідження бугаїв-плідників голштинської породи за екстер'єрним типом їхніх дочок в умовах конкретного господарства. Для оцінки використовували сучасну методику лінійної класифрікації рекомендованою міжнародною організацією ICAR. Оцінювали корів у віці першої лактації на 2-4 місяці після отелення за 100-бальною та 9-ти бальною шкалою. Дослідження проведені у стаді ПП „Буринське” Підліснівської філії Сумського району. Порівняльний аналіз бугаїв дозволив виявити серед них поліпшувачів екстер'єрного типу за лінійною оцінкою їхніх дочок. За результатами оцінки бугаїв-плідників за 100-бальною системою лінійної класифікації вищими балами за розвиток групових ознак та фрінальною оцінкою виявилися бугаї Макдадді 138438344 (83,5-84,6 та 84,2 балу) та Дж. Руебен 137936344 (83,4-84,4 та 83,7 балу). Загалом дочки усіх оцінених голштинських бугаїв-плідників успадкували добрий розвиток усіх статей екстер'єру, про що свідчать оцінки описових ознак, рівень яких перевищує середнє значення їхнього розвитку в породі. Виключення стосується лише розміщення передніх та задніх дійок і кута тазових кінцівок у дочок окремих плідників. Продуктивність дочок оцінених за лінійною класифікацією бугаїв-плідників за величиною надою за лактацію залежить від рівня оцінки статей, які характеризують вираженість молочного типу ( $r=0,244-0,424)$, розвиток тулуба $(r=0,286-0,386)$, вимені $(r=0,312-0,461)$ та фінальної оиінки (r=0,318-0,475) з достовірністю $P<0,05-0,001$. Встановлена додатна, за різного ступеня достовірності, кореляція між величиною надою та описовими ознаками: висотою у крижах $(r=0,124-0,303)$, глибиною тулуба $(r=0,226$ 0,324), кутастістю ( $r=0,277-0,395)$, шириною заду ( $r=0,214-0,287)$, поставою тазових кінцівок $(r=0,217-0,286)$, прикріпленням передніх часток вимені $(r=0,244-0,384)$ та від'ємну - між вгодованістю та надоєм $(r=-0,118 \ldots-0,322)$. У процесі удосконалення стада з розведення голштинської породи за екстер'єром необхідно активно використовувати бугаївполіпшувачів, оцінених за методикою лінійної класиффікації їніх дочок, що забезпечить ефективність селекції стада як за типом, так і за молочною продуктивністю.

Ключові слова: голштинська порода, лінійна оцінка типу, кореляція, статі екстер'єру.

DOI: https://doi.org/10.32845/bsnau.lvst.2020.4.1

Ефективність селекційного удосконалення високопродуктивного стада з розведення молочної худоби за ознаками молочної продуктивності та екстер'єрного типу істотним чином залежить від раціонального підбору бугаївплідників, особливо поліпшувачів за оцінкою екстер'єру їхніх дочок $[3,10,25,30,31,34]$

Через це, вдалий підбір бугая-плідника задля поліпшення екстер'єру корів молочного стада, досить важлива та відповідальна задача селекціонера. Тим більше, що неодноразово доведено, що у молочному скотарстві роль спадковості бугаїв-плідників у генетичному поліпшенні порід досягла 90-95\% [2].

Про суттєвий вплив спадковості бугаїв-батьків на генетичне удосконалення молочної худоби високопродуктивних стад, особливо на сучасному етапі їхнього розведення та селекції, повідомляється в публікаціях інших науковців [1, $5,15]$, тому що будь-яка важлива провідна господарськи корисна ознака, особливо обмежена статтю, перш ніж проявиться у самок, має бути апробована у самців.

3 огляду на це, ознаки будови тіла та якісних показників вимені, які характеризують бажаний екстер'єрний тип худоби молочних порід, поряд з молочною продуктивністю, $є$ провідними селекційними ознаками при їхньому поліпшенні.

Враховуючи незаперечний факт з приводу того, що поліпшення молочної худоби здійснюється через бугаївплідників, підбір є чи не найголовнішим заходом у системі селекції стад. Саме тому в аспекті важливості вирішення проблеми підбору, яка щоразу виникає на черговому етапі закріплення бугая-плідника для конкретного селекційного стада, дуже важливим моментом $є$ об'єктивне визначення селекційної ситуації, особливо у напрямку формування екстер'єрного типу маточного поголів'я загалом та у межах використаних бугаїв-плідників зокрема, оскільки якраз завдяки їм успадковується як бажаний розвиток статей будови тіла, так і їхні недоліки $[4,18]$. Крім того, групою науковців доведено існування позитивних кореляцій між недоліками статей екстер'єру та лінійними ознаками [6].

Актуальність та мета даного дослідження вмотивована популяційно-генетичним аспектом, через те, що за безліччю досліджень як вітчизняними науковцями $[7,9,14$ $23,24,26,28,29]$, так і зарубіжними [35, 36, 37, 40, 41, 42] доведено існування зв'язку між ознаками екстер'єрного типу тварин та їхньою продуктивністю, відтворною здатністю та тривалістю продуктивного використання.

Матеріали та методи досліджень. Експерименти 
проведені за використання поголів'я корів голштинської породи підприємства ПП „Буринське” Підліснівської філії, що в Сумському районі. Оцінка корів-первісток за лінійними ознаками екстер'єрного типу проводилася за методикою запропонованою співробітниками Сумського НАУ та Інституту розведення і генетики тварин НААН [27] згідно рекомендацій ICAR $[11,38]$. Оцінювались тварини у віці 2-4 місяців після отелення за двома системами - 9-бальною, з лінійним описом 18 статей екстер'єру і 100-бальною системою класифікації з урахуванням чотирьох комплексів селекційних ознак, які характеризують: вираженість молочного типу, розвиток тулуба, стан кінцівок і морфологічні якості вимені. Кожен екстер'єрний комплекс оцінювався незалежно маючи свій ваговий коефіцієнт у загальній оцінці (30) тварини: молочний тип (МТ) - 15\%, тулуб (Т) - 20\%; кінцівки (К) $-25 \%$ та вим'я (В) $-40 \%$.

Фінальну оцінку типу визначали за формулою:

$$
3 O=(M T \cdot 0,15)+(T \cdot 0,20)+(K \cdot 0,25)+(B \cdot 0,40)
$$

Дані експериментальних досліджень опрацьовували біометричними методами на ПК у середовищі Microsoft Office Excel за використання програмного забезпечення за формулами, наведеними Е. К. Меркурьевой [13].

Результати досліджень. За результатами оцінки бугаїв-плідників за типом їхніх дочок, оцінених за 100бальною системою лінійної класифікації, вищими балами за розвиток групових ознак та фрінальною оцінкою виявилися бугаї - Ф.Л. Макдадді 138438344 (83,5-84,6 та 84,2 балу; лінія Маршала 2290977) та Дж. Руебен 137936344 (83,4-84,4 та 83,7 балу; лінія Старбака 352790). Істотно нижчу оцінку отримали також два плідники К.Ф.П. Долс 139719547 (80,682,8 та 81,3 балу; лінія П.Ф.А. Чіфа 1427381) та З.П.Темпо $53774726(80,8-82,8$ та 81,6 балу; лінія П.Ф.А. Чіфра 1427381), табл. 1.

Характеристика бугаїв-плідників підконтрольного стада,

Таблиця 1 оцінених за 100-бальною системою лінійної класифікації, $\mathrm{X} \pm$ S.E.

\begin{tabular}{|c|c|c|c|c|c|c|}
\hline \multirow{2}{*}{$\begin{array}{c}\text { Кличка та } \\
\text { ідентифікаційний } \\
\text { № бугая-плідника }\end{array}$} & \multirow[b]{2}{*}{$\mathrm{n}$} & \multicolumn{4}{|c|}{ Комплекс екстер'єрних статей, що характеризують: } & \multirow{2}{*}{$\begin{array}{c}\text { Фінальна } \\
\text { оцінка }\end{array}$} \\
\hline & & $\begin{array}{c}\text { молочний } \\
\text { тип }\end{array}$ & тулуб & кінцівки & вим'я & \\
\hline $\begin{array}{l}\text { Ф.Л. Макдадді } \\
138438344\end{array}$ & 36 & $84,3 \pm 0,31$ & $84,6 \pm 0,33$ & $83,5 \pm 0,31$ & $84,5 \pm 0,38$ & $84,2 \pm 0,33$ \\
\hline $\begin{array}{l}\text { К.Ф.П. Долс } \\
139719547\end{array}$ & 22 & $80,6 \pm 0,38$ & $82,8 \pm 0,32$ & $81,7 \pm 0,37$ & $80,6 \pm 0,39$ & $81,3 \pm 0,35$ \\
\hline $\begin{array}{l}\text { Г.Х.Б. Трей } \\
66155210\end{array}$ & 29 & $82,8 \pm 0,34$ & $83,3 \pm 0,35$ & $82,5 \pm 0,29$ & $82,2 \pm 0,34$ & $82,6 \pm 0,36$ \\
\hline $\begin{array}{l}\text { 3.П. Темпо } \\
53774726 \\
\end{array}$ & 27 & $80,8 \pm 0,28$ & $82,3 \pm 0,23$ & $82,8 \pm 0,26$ & $80,8 \pm 0,27$ & $81,6 \pm 0,28$ \\
\hline $\begin{array}{l}\text { Дж. Руебен } \\
137936344\end{array}$ & 33 & $83,5 \pm 0,25$ & $84,4 \pm 0,25$ & $83,4 \pm 0,26$ & $83,7 \pm 0,26$ & $83,7 \pm 0,24$ \\
\hline
\end{tabular}

У системі лінійної класифікації корів за 100-бальною шкалою до групи статей екстер'єру, які характеризують молочний тип включені холка, міжреберна відстань, гармонія, кістяк, шия і голова. При цьому оцінюється фізіологічна здатність тварини до високих надоїв та тривалості продуктивного використання. Корови вираженого молочного типу мають відрізнятися кутастими формами, добрим розвитком тіла, що гармонійно поєднується з пропорційно розвиненими його окремими його частинами [32]. У межах оцінки комплексу лінійних ознак екстер'єру, які характеризують молочний тип корів оцінюваних бугаїв-плідників, спостерігалася достовірна мінливість із варіацією оцінок від 80,6 (дочки бугая К.Ф.П.Долса) до 84,3 балу (дочки бугая Ф.Л. Макдадді). Різниця між цими оцінками є високодостовірною і становить 3,7 бала $(P<0,001)$.

Лінійна оцінка комплексу екстер'єрних статей, які характеризують стан розвитку тулуба корів (висота, довжина та глибина тулуба, міцність, ширина, положення та довжина крижів), досить важлива у селекційному значенні, оскільки вони вказують на рівень загального розвитку тварини у довжину та ширину, на розвиток грудної клітини та заду і позитивно корелюють 3 продуктивністю тварин $[19,28]$. Широкі груди - це показник здоров'я тварини у цілому, вони свідчать про добрий розвиток легенів та серця, які забезпечують функціональну міцність та надійність корів упродовж тривалого продуктивного використання. За глибокого тулуба визначається можливість тварини вживати велику кількість грубих кормів на противагу концентрованим [32]. Цей ком- плекс ознак відрізнявся найвищими показниками оцінки. Його мінливість у дочок бугаїв підконтрольного стада становила 82,3-84,6 балу 3 достовірною різницею між крайніми варіантами 2,3 балу $(P<0,001)$.

Оцінка кінцівок розглядається в аспекті здатності тварини до вільного руху та навантажень. Оцінюється стан задніх і передніх ніг та ратиць. Від міцності та стану ознак, які характеризують кінцівки (постава передніх та задніх ніг, стан кута скакального суглоба, ратиці, бабки, зап'ястя, міжратицева щілина) істотним чином залежить тривалість господарського використання тварин в сучасних умовах промислової технології утримання. Варіативність оцінок за стан кінцівок дочок оцінюваних бугаїв-плідників дещо менша і змінюється у межах 81,5-82,9 балу 3 достовірною різницею між крайніми відхиленнями 1,8 балу при $\mathrm{P}<0,001$.

Оцінка молочної системи передбачає огляд будови та структури вимені, при цьому перевага надається ознакам, від яких залежать високий надій, пристосованість до машинного доїння, до того ж високоякісне вим'я менш уразливе до травмування та захворювань. До того ж фінальна оцінка корови за екстер'єрний тип істотним чином залежить від величини оцінки за комплекс ознак, які характеризують вим'я, через найбільший ваговий коефіцієнт $(40,0 \%)$ у загальній оцінці лінійної класифікації. Це свідчить про неабияку важливість цього комплексу для оцінки молочної худоби за екстер'єром. За лінійними ознаками вимені у підконтрольному стаді кращими за розвитком морфологічних ознак вимені відрізнялися дочки бугаїв Ф.Л. Макдадді (84,5 балу) 
та Дж. Руебена (83,7 балу), що у порівнянні з найнижчою оцінкою одноліток, отриманих від бугаїв К.Ф.П. Долса та 3.П. Темпо, становило достовірну різницю у 2,9-3,9 балу $(P<0,001)$.

Виразну уяву щодо розвитку особливо важливих статей екстер'єру оцінюваної корови, відокремлено від групових, які мають економічну, функціональну, або селекційну цінність, дає описова система лінійної оцінки. За цією системою обов'язково описуються визначені ICAR [38] ознаки екстер'єру корови, що включені до характеристик групових ознак молочного типу, тулуба, кінцівок та вимені з урахуванням певного переліку недоліків, які найчастіше зустрічаються у тварин. Згідно з методикою [27], при оцінці тварин за єдиною 9-ти бальною шкалою середня вираженість ознаки оцінюється у п'ять балів, а біологічні відхилення у бік погіршення розвитку із зменшенням балів до одного і, навпаки, якщо розвиток ознаки зростає, оцінка збільшується до дев'яти балів. Разом з тим, максимальна оцінка у 9 балів не завжди характеризує бажаний тип розвитку статі екстер'єру. Найперше це стосується таких ознак, як положення заду, кут скакального суглоба, глибина вимені, розміщення та довжина дійок.

Отримана за результатами оцінки істотна мінливість описових ознак екстер'єру у дочок оцінюваних бугаївплідників демонструє істину ситуацію щодо передавання ними у спадок лінійних ознак, кожна із яких має важливу функціональну або селекційну значущість. Рівень оцінок, наведених у таблиці 2 свідчить, що показники 9-тибальної шкали описових ознак корів-первісток мають істотний рівень мінливості у залежності від бугаїв-плідників та самих ознак. Вищі бали за оцінку описових статей отримали дочки бугаїв Ф.Л. Макдадді, Г.Х.Б. Трея та Дж. Руебена. Дещо нижчі показники оцінки виявлено у дочок плідників К.Ф.П. Долса та 3.П.Темпо.

Загалом дочки усіх оцінених голштинських бугаївплідників стада ПП "Буринське” успадкували добрий розви- ток усіх статей екстер'єру, про що свідчать оцінки описових ознак, рівень яких перевищує середнє значення їхнього розвитку в породі. Виключення стосується лише розміщення передніх та задніх дійок і кута тазових кінцівок у дочок окремих плідників.

За показниками оцінки описових лінійних ознак дочки оцінюваних бугаїв, не дивлячись на достовірну їхню мінливість, відрізняються добрим розвитком за висотою $(5,7-7,7$ балу), шириною грудей (6,0-6,8 балу), глибиною тулуба (5,87,5 балу), кутастістю (5,5-7,3 балу), шириною заду (5,2-6,8 балу), поставою задніх кінцівок (5,4-7,7 балу), прикріпленням передніх (5,3-7,3 балу) та задніх часток вимені (5,4-6,8 балу), центральною зв'язкою (5,1-7,1 балу) та переміщенням (5,4-7,5 балу). Вищі оцінки отримали дочки бугаїв Ф.Л. Макдадді, Г.Х.Б. Трея та Дж. Руебена.

Відомо, що характер мінливості господарськи корисних ознак залежить від низки генетичних та паратипових чинників. Мінливість, один із найважливіших популяційногенетичних параметрів, постачає селекціонерам безліч різноманітних форм і дозволяє проводити відповідний добір згідно з вибраним напрямом селекції [3, 12]. Проте селекційний прогрес у тваринництві забезпечується закріпленням у подальших поколіннях лише генетичної мінливості [16]. 3 іншого боку, висока мінливість свідчить про недостатню консолідованість тварин за тією чи іншою ознакою.

Порівнюючи рівень коефіцієнтів варіації лінійних ознак (табл. 3) відмічаємо, що у піддослідного поголів'я корів, незалежно від походження за батьком, у межах кожної описової ознаки, виявлено існування високої фенотипової мінливості. Особливо це помітно у дочок бугаїв-плідників 3 низькими оцінками за груповими ознаками (Долс та Темпо), що свідчить про їхню взаємообумовленість. Тоді як у дочок плідників з вищими оцінками за групові ознаки, мінливість описових статей дещо менша, що свідчить про їхню вищу консолідованість за екстер'єрним типом.

Оцінка бугаїв-плідників за описовими ознаками

Таблиця 2 екстер'єру 9-ти бальної шкали, $\mathbf{x} \pm$ S.E.

\begin{tabular}{|c|c|c|c|c|c|c|}
\hline \multicolumn{2}{|c|}{$\begin{array}{c}\text { Описова ознака } \\
\text { екстер'єру }\end{array}$} & Макдадді & Долс & Трей & Темпо & Руебен \\
\hline \multicolumn{2}{|c|}{ висота у крижах } & $7,7 \pm 0,15$ & $5,9 \pm 0,21$ & $6,2 \pm 0,23$ & $5,7 \pm 0,23$ & $6,4 \pm 0,21$ \\
\hline \multicolumn{2}{|l|}{ ширина грудей } & $6,2 \pm 0,16$ & $6,8 \pm 0,24$ & $6,5 \pm 0,22$ & $6,7 \pm 0,22$ & $6,0 \pm 0,17$ \\
\hline \multicolumn{2}{|l|}{ глибина тулуба } & $7,5 \pm 0,17$ & $6,5 \pm 0,21$ & $6,8 \pm 0,21$ & $5,8 \pm 0,19$ & $7,2 \pm 0,19$ \\
\hline \multicolumn{2}{|l|}{ кутастість } & $7,3 \pm 0,20$ & $5,5 \pm 0,18$ & $6,5 \pm 0,19$ & $5,7 \pm 0,22$ & $6,9 \pm 0,23$ \\
\hline \multicolumn{2}{|l|}{ положення заду } & $5,2 \pm 0,15$ & $6,1 \pm 0,19$ & $4,9 \pm 0,15$ & $5,8 \pm 0,21$ & $5,3 \pm 0,18$ \\
\hline \multicolumn{2}{|l|}{ ширина заду } & $6,8 \pm 0,20$ & $5,3 \pm 0,16$ & $6,5 \pm 0,21$ & $5,2 \pm 0,24$ & $6,6 \pm 0,16$ \\
\hline \multicolumn{2}{|l|}{ кут тазових кінцівок } & $5,3 \pm 0,15$ & $4,5 \pm 0,17$ & $5,2 \pm 0,17$ & $4,2 \pm 0,18$ & $5,1 \pm 0,17$ \\
\hline \multicolumn{2}{|c|}{ постава зад. кінцівок } & $7,7 \pm 0,22$ & $5,5 \pm 0,19$ & $7,1 \pm 0,18$ & $5,4 \pm 0,22$ & $6,4 \pm 0,15$ \\
\hline \multicolumn{2}{|l|}{ кут ратиці } & $6,8 \pm 0,24$ & $3,4 \pm 0,28$ & $6,1 \pm 0,16$ & $4,4 \pm 0,19$ & $6,2 \pm 0,22$ \\
\hline \multirow{2}{*}{$\begin{array}{l}\text { прикріплення } \\
\text { вимені }\end{array}$} & переднє & $7,3 \pm 0,25$ & $5,8 \pm 0,23$ & $6,5 \pm 0,17$ & $5,3 \pm 0,22$ & $6,8 \pm 0,24$ \\
\hline & заднє & $6,8 \pm 0,26$ & $5,4 \pm 0,19$ & $6,6 \pm 0,18$ & $5,5 \pm 0,21$ & $6,4 \pm 0,26$ \\
\hline \multicolumn{2}{|l|}{ центральна зв'язка } & $7,1 \pm 0,15$ & $5,2 \pm 0,27$ & $6,5 \pm 0,23$ & $5,1 \pm 0,27$ & $6,8 \pm 0,32$ \\
\hline \multicolumn{2}{|l|}{ глибина вимені } & $7,2 \pm 0,22$ & $5,1 \pm 0,26$ & $6,1 \pm 0,21$ & $5,2 \pm 0,24$ & $6,7 \pm 0,27$ \\
\hline \multirow{2}{*}{ розміщення дійок } & передніх & $4,4 \pm 0,19$ & $4,6 \pm 0,19$ & $5,4 \pm 0,16$ & $4,3 \pm 0,23$ & $4,8 \pm 0,19$ \\
\hline & задніх & $4,9 \pm 0,14$ & $4,8 \pm 0,17$ & $5,6 \pm 0,17$ & $4,2 \pm 0,21$ & $5,0 \pm 0,17$ \\
\hline \multicolumn{2}{|l|}{ довжина дійок } & $5,1 \pm 0,15$ & $5,7 \pm 0,18$ & $5,2 \pm 0,14$ & $5,4 \pm 0,16$ & $5,1 \pm 0,17$ \\
\hline \multicolumn{2}{|l|}{ переміщення } & $6,8 \pm 0,18$ & $6,2 \pm 0,17$ & $7,5 \pm 0,21$ & $5,4 \pm 0,18$ & $6,4 \pm 0,21$ \\
\hline \multicolumn{2}{|l|}{ вгодованість } & $5,5 \pm 0,23$ & $6,8 \pm 0,21$ & $6,5 \pm 0,22$ & $6,8 \pm 0,21$ & $6,2 \pm 0,22$ \\
\hline
\end{tabular}

Вмотивованість використання лінійної оцінки та добору корів молочної худоби за бажаним екстер'єрним типом з самого початку ії запровадження і до тепер зумовлена найперше існуючою кореляцією між розвитком як окремих 
статей, так і пропорцій будови тіла з ознаками молочної продуктивності корів, тривалістю та ефективністю їхнього продуктивного використання, відтворною здатністю та здоров'ям. Це неодноразово було доведено дослідженнями, спрямованими на виявлення таких зв'язків [8, 17, 20, 21, 22, 33, 39].

Згідно з рекомендаціями ICAR публікуються результати випробування бугаїв у межах стандартного відхилення від 0 до 1,0. Показники оцінки найбільш розповсюджених бугаїв-плідників публікуються у формі гістограм зі стандартним середньоквадратичним відхиленням від $+3 \sigma$ до $-3 \sigma$.
Альтернативний варіант: значення 100-відсоткового стандартного відхилення за базою даних популяції, коли це стандартне відхилення стосується ситуації оцінювання корів [11]. При цьому для унаочнення стандартне відхилення становить число 12.

Аналіз графріка екстер'єрного профрілю голштинського бугая Ф.Л. Макдадді 138438344 наочно вказує на відмінну характеристику його оцінки за типом дочок, рис. 1. Згідно 3 екстер'єрним профрілем оцінки групових ознак, його дочки відрізняються добрим вираженням молочного типу, аналогічним розвитком тулуба, кінцівок та вимені.

Таблиця 3

Мінливість розвитку описових ознак екстер'єру дочок бугаїв-плідників, (Cv, \%)

\begin{tabular}{|c|c|c|c|c|c|c|}
\hline \multicolumn{2}{|c|}{$\begin{array}{c}\text { Описова ознака } \\
\text { екстер'єру }\end{array}$} & Макдадді & Долс & Трей & Темпо & Руебен \\
\hline \multicolumn{2}{|c|}{ висота у крижах } & 12,4 & 23,6 & 12,8 & 21,3 & 13,5 \\
\hline \multicolumn{2}{|c|}{ ширина грудей } & 16,5 & 19,5 & 18,0 & 23,1 & 18,8 \\
\hline \multicolumn{2}{|c|}{ глибина тулуба } & 10,7 & 22,2 & 21,2 & 19,2 & 20,6 \\
\hline \multicolumn{2}{|l|}{ кутастість } & 19,4 & 25,3 & 15,9 & 16,7 & 19,4 \\
\hline \multicolumn{2}{|c|}{ положення заду } & 19,2 & 22,2 & 17,6 & 25,8 & 20,2 \\
\hline \multicolumn{2}{|l|}{ ширина заду } & 15,5 & 24,8 & 13,6 & 28,3 & 14,7 \\
\hline \multicolumn{2}{|c|}{ кут тазових кінцівок } & 11,7 & 27,5 & 16,1 & 19,1 & 13,8 \\
\hline \multicolumn{2}{|c|}{ постава задніх кінцівок } & 12,6 & 26,6 & 17,4 & 19,4 & 12,3 \\
\hline \multicolumn{2}{|c|}{ кут ратиці } & 15,8 & 28,2 & 16,6 & 21,3 & 14,2 \\
\hline \multirow{2}{*}{$\begin{array}{l}\text { прикріплення } \\
\text { вимені }\end{array}$} & переднє & 18,6 & 26,4 & 18,4 & 25,8 & 16,5 \\
\hline & заднє & 17,5 & 27,2 & 14,1 & 24,5 & 17,1 \\
\hline \multicolumn{2}{|c|}{ центральна зв'язка } & 12,4 & 29,7 & 18,6 & 19,7 & 15,2 \\
\hline \multicolumn{2}{|c|}{ глибина вимені } & 15,7 & 26,8 & 19,5 & 23,8 & 18,8 \\
\hline \multirow{2}{*}{$\begin{array}{l}\text { розміщення } \\
\text { дійок }\end{array}$} & передніх & 14,8 & 22,1 & 18,3 & 24,9 & 16,2 \\
\hline & задніх & 15,5 & 21,3 & 17,2 & 22,6 & 14,8 \\
\hline \multicolumn{2}{|l|}{ довжина дійок } & 11,2 & 19,5 & 17,4 & 13,2 & 16,6 \\
\hline \multicolumn{2}{|l|}{ переміщення } & 13,6 & 17,8 & 15,6 & 20,5 & 15,4 \\
\hline \multicolumn{2}{|l|}{ вгодованість } & 13,9 & 18,9 & 17,4 & 18,7 & 15,6 \\
\hline
\end{tabular}

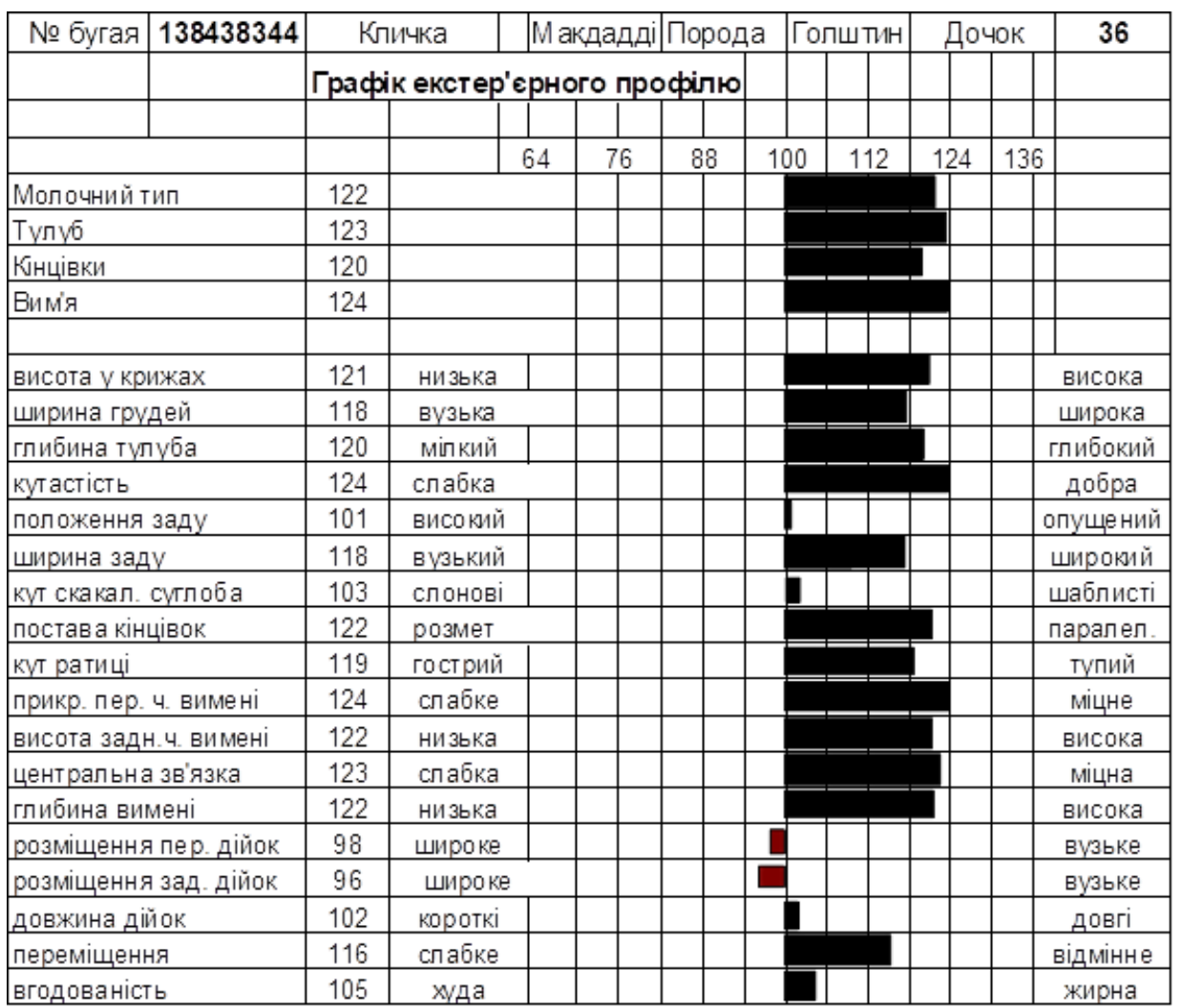

Рис. 1. Графік екстер'єрного профілю дочок бугая-плідника 
Аналізуючи розвиток окремих описових статей, які успадкували дочки бугая Ф.Л. Макдадді, спостерігаємо у них високий зріст, добрий розвиток грудей у ширину, а тулуба у глибину, відмінно виражену кутастість, майже оптимальний нахил крижів, достатньо широкий зад, близьку до паралельної поставу задніх ніг, незначний тупий кут ратиць, як недолік - у окремих особин спостерігається слабко виражена шаблистість тазових кінцівок, незначне широке розташування передніх та задніх дійок. Вим'я добре характеризує його міцне прикріплення передніх та задніх часток з достатньо вираженою, глибокою центральною зв'язкою. Як наслідок, високі оцінки цих трьох ознак вимені, які забезпечують міцність його прикріплення, характеризують стан наступної ознаки - глибину вимені. Дочки бугая Ф.Л. Макдадді успадкували високе розташування вимені відносно умовно проведеної лінії на рівні скакальних суглобів.

На рис. 2 представлено графік екстер'єрного профрілю бугая голштинської породи К.Ф.П. Долса 139719547. Гістограма, що відображає значення стандартного відхилення у порівнянні зі 100-відсотковою базою даних популяції, свідчить про досить таки не задовільну оцінку цього плідника. Із чотирьох груп екстер'єрних комплексів 100бальної шкали дещо краще вирізняється розвиток лінійних ознак, які характеризують тулуб.

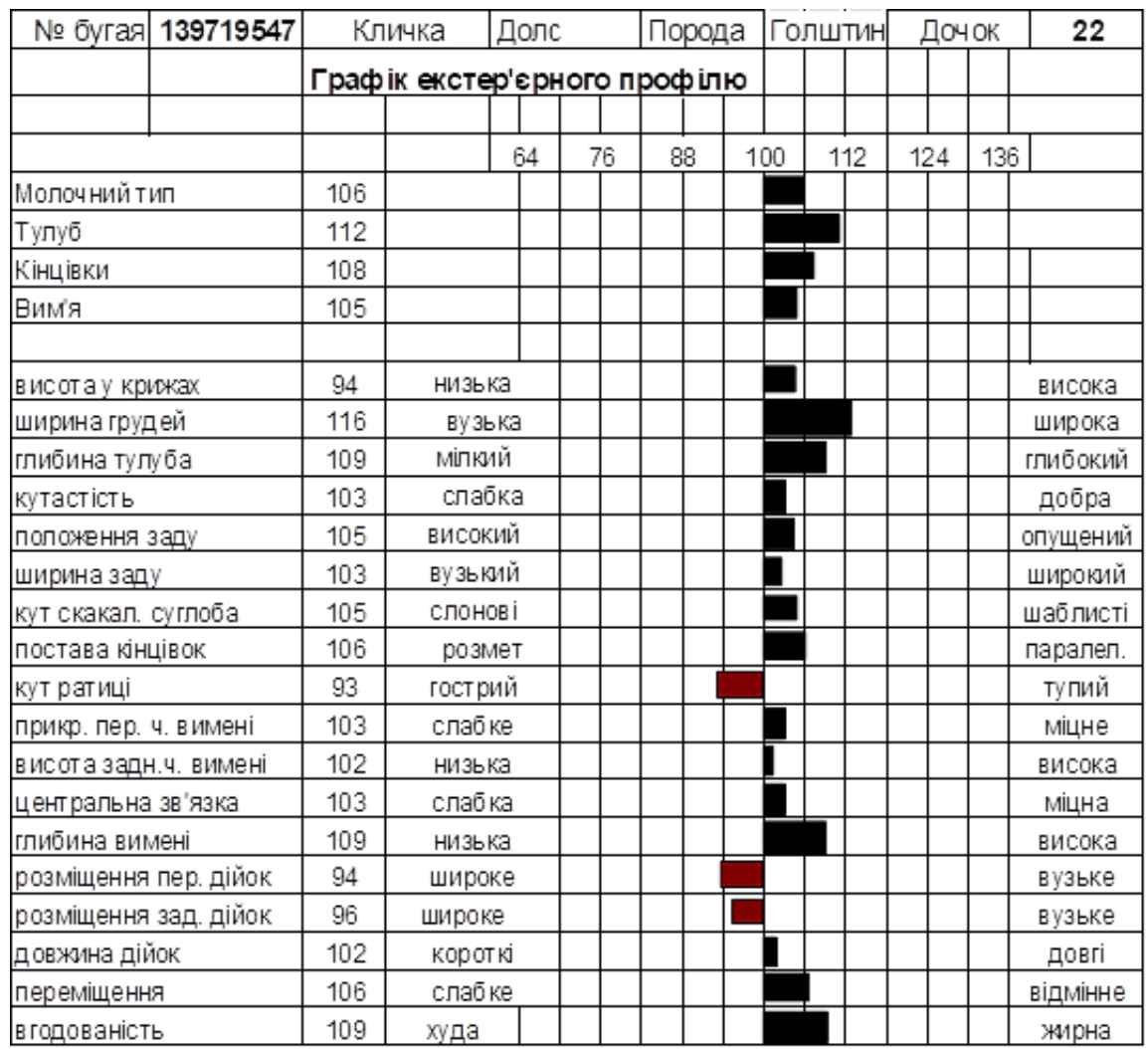

Рис. 2. Графік екстер'єрного профілю дочок бугая-плідника голштинської породи К.Ф.П. Долса 139719547

Оцінка окремих описових ознак бугая К.Ф.П. Долса 139719547 свідчить, що за висотою та за більшістю ознак його дочки вище від середнього рівня в породі, вони мають чуть кращий розвиток грудей у ширину та глибину, але дуже слабко виражену кутастість, як недолік - дещо спущені крижі, шаблистість, гострий кут ратиць, морфологічні ознаки вимені виражені досить слабко, особливо ознаки, які відповідають за прикріплення вимені.

Успішна селекція молочної худоби у напрямку нарощування генетичного потенціалу молочної продуктивності та екстер'єрного типу значною мірою залежить від одного із найважливіших чинників популяційної генетики - співвідносної мінливості між цими селекціонованими ознаками. На сучасному етапі консолідації тварин за типом та молочною продуктивністю, коли метод розведення української чорнорябої молочної породи «у собі» замінено на поглинання висококровного за голштином масиву тварин чистопородни- ми голштинськими плідниками, досить важливо враховувати ступінь зв'язку між лінійними ознаками екстер'єру корів 3 їхньою молочною продуктивністю, особливо коли це стосується бугаїв-плідників.

Отримані нами додатні та достовірні зв'язки більшості комплексів лінійних ознак з величиною надою дочок оцінених бугаїв-плідників піддослідного підприємства за першу лактацію переконливо свідчать про провідну роль їхньої спадковості у поліпшенні екстер'єрного типу свого потомства, табл. 4.

Продуктивність корів-первісток стада ПП "Буринське" за величиною надою за лактацію залежить від рівня оцінки статей, які характеризують вираженість молочного типу дочок оцінених за лінійною класифікацією бугаїв-плідників $(r=0,244-0,424)$, розвиток тулуба $(r=0,286-0,386)$, вимені $(r=0,312-0,461)$ та фінальної оцінки $(r=0,318-0,475)$ з достовірністю $\mathrm{P}<0,05-0,001$. 
Зв'язок оцінки за комплексами лінійних ознак 3 величиною надою дочок бугаїв-плідників за першу лактацію (r)

\begin{tabular}{|c|c|c|c|c|c|c|}
\hline \multirow{2}{*}{$\begin{array}{c}\text { Кличка та ідентифікаційний } \\
\text { № бугая-плідника }\end{array}$} & \multirow{2}{*}{$\mathrm{n}$} & \multicolumn{4}{|c|}{ Група ознак екстер'єру, які характеризують: } & \multirow{2}{*}{$\begin{array}{c}\text { Фінальна } \\
\text { оцінка }\end{array}$} \\
\hline & & молочний тип & тулуб & кінцівки & вим'я & \\
\hline Ф.Л.Макдадді 138438344 & 36 & $0,424^{* * *}$ & $0,377^{* * *}$ & $0,187^{*}$ & $0,461^{* * *}$ & $0,475^{\star * *}$ \\
\hline К.Ф.П.Долс 139719547 & 22 & $0,282^{* *}$ & $0,286^{\star *}$ & $0,155^{*}$ & $0,312^{* *}$ & $0,318^{* *}$ \\
\hline Г.Х.Б.Трей 66155210 & 29 & $0,366^{* * *}$ & $0,353^{* *}$ & $0,198^{*}$ & $0,417^{* * *}$ & $0,424^{* * *}$ \\
\hline 3.П.Темпо 53774726 & 27 & $0,244^{* *}$ & $0,301^{* *}$ & $0,155^{\star}$ & $0,335^{* *}$ & $0,339^{* *}$ \\
\hline Дж.Руебен 137936344 & 33 & $0,368^{* * *}$ & $0,386^{\star * *}$ & $0,137^{*}$ & $0,324^{* * *}$ & $0,336^{\star \star *}$ \\
\hline
\end{tabular}

Аналіз показників співвідносної мінливості описових статей екстер'єру з продуктивністю корів-первісток загалом виявив позитивну тенденцію щодо існування додатного зв'язку більшості із них з величиною надою у межах бугаїв- плідників стада, табл. 5. До них відносяться у першу чергу ті, які несуть функціональні навантаження, або розвиток яких зв'язаний з іншими статями, від яких залежить продуктивність тварин.

Зв'язок описових ознак екстер'єру бугаїв-плідників

Таблиця 5 3 величиною надою за першу лактацію

\begin{tabular}{|c|c|c|c|c|c|}
\hline Описова ознака екстер'єру & Макдадді & Долс & Трей & Темпо & Руебен \\
\hline висота у крижах & $0,303^{* *}$ & $0,214^{*}$ & $0,266^{*}$ & $0,124^{*}$ & $0,244^{* *}$ \\
\hline ширина грудей & 0,077 & 0,155 & 0,104 & 0,125 & 0,074 \\
\hline глибина тулуба & $0,324^{* * *}$ & $0,282^{* *}$ & $0,311^{* *}$ & $0,226^{*}$ & $0,293^{* *}$ \\
\hline кутастість & $0,395^{\star \star *}$ & $0,328^{* *}$ & $0,362^{* *}$ & $0,277^{*}$ & $0,345^{\star *}$ \\
\hline положення заду & 0,131 & 0,118 & 0,114 & 0,091 & 0,122 \\
\hline ширина заду & $0,287^{* *}$ & $0,251^{* *}$ & $0,272^{* *}$ & $0,214^{*}$ & $0,242^{*}$ \\
\hline кут тазових кінцівок & 0,112 & 0,081 & 0,081 & $-0,022$ & 0,092 \\
\hline постава задніх кінцівок & $0,286^{* *}$ & $0,232^{*}$ & $0,248^{*}$ & $0,217^{*}$ & $0,241^{*}$ \\
\hline кут ратиці & $0,196^{*}$ & 0,122 & $0,181^{*}$ & 0,063 & 0,118 \\
\hline переднє прикріплення вимені & $0,384^{* * *}$ & $0,282^{* *}$ & $0,298^{* *}$ & $0,244^{*}$ & $0,284^{* *}$ \\
\hline заднє прикріплення вимені & $0,292^{* *}$ & $0,194^{*}$ & $0,264^{* *}$ & $0,164^{*}$ & $0,268^{* *}$ \\
\hline центральна зв'язка & $0,312^{* *}$ & $0,168^{*}$ & $0,277^{* *}$ & $0,181^{*}$ & $0,145^{*}$ \\
\hline глибина вимені & 0,083 & 0,137 & 0,098 & $-0,027$ & $-0,093$ \\
\hline розміщення передніх дійок & $-0,056$ & 0,052 & 0,088 & $-0,053$ & 0,102 \\
\hline розміщення задніх дійок & $-0,024$ & 0,047 & $-0,107$ & $-0,042$ & 0,039 \\
\hline довжина дійок & 0,083 & 0,063 & $-0,018$ & 0,088 & $-0,056$ \\
\hline переміщення & $0,187^{*}$ & 0,122 & $0,128 *$ & $0,136^{*}$ & $0,175^{*}$ \\
\hline вгодованість & $-0,322^{* *}$ & $-0,248^{*}$ & $-0,265^{\star *}$ & $-0,118^{*}$ & $-0,228^{* *}$ \\
\hline
\end{tabular}

Примітка. * достовірно при $P<0,05$; ** - при $P<0,01$; **-

Аналізуючи результати обрахунків зв'язку описових статей екстер'єру з величиною надою за лактацію дочірніх нащадків бугаїв-плідників стада, спостерігаємо додатну, за різного ступеня достовірності, кореляцію між величиною надою та висотою у крижах ( $\mathrm{r}=0,124-0,303)$, глибиною тулуба ( $r=0,226-0,324)$, кутастістю ( $r=0,277-0,395)$, шириною заду ( $r=0,214-0,287)$, поставою тазових кінцівок $(r=0,217-0,286)$, прикріпленням передніх часток вимені (r=0,244-0,384) та від'ємну - між вгодованістю та надоєм ( $r=-0,118 \ldots-0,322)$.

Кореляція інших морфологічних ознак вимені з надоєм несуттєва і варіює у досить широких межах як з додатними коефіцієнтами, так і з від'ємними. Від'ємна спрямованість кореляцій у більшості дочок оцінюваних бугаїв виявлена за ознаками розміщення передніх та задніх дійок, оскіль- ки із наповненням вимені молоком воно збільшується в об'ємі.

Висновки. У процесі удосконалення стад з розведення голштинської породи за екстер'єром необхідно активно використовувати бугаїв-поліпшувачів, оцінених за методикою лінійної класифікації їхніх дочок, що забезпечить ефективність селекції стад як за типом, так і за молочною продуктивністю.

Задля гарантованого удосконалення корів піддослідного стада за екстер'єром використовувати у підборі голштинських бугаїв-плідників Ф.Л. Макдадді 138438344 та Дж. Руебена 137936344, які за результатами оцінки виявилися поліпшувачами типу своїх дочок.

\section{Список використаної літератури:}

1. Антал Л. Размышления на тему: "бык - половина стада". Молочное и мясное скотоводство. 2004. № 1. С. 16-20.

2. Басовський М. 3,. Рудик І. А., Буркат В. П. Вирощування, оцінка і використання плідників. К.: Урожай, 1992.216 с.

3. Ефимова Л. В., Ростовцева Н. М., Кошурина О. Н. Линейная оценка экстерьера дочерей быков красно-пестрой и голштинской пород в Красноярском крае. Мол. и мясное скотоводство. 2015. № 8. С. 20-22.

4. Карликов Д. В., Клейменова И. В. Недостатки и пороки экстерьера черно-пестрого скота. Зоотехния. 1997. № 1. С. $8-10$.

5. Клопенко Н. І., Рудик І. А. Використання селекційно-генетичних параметрів у селекції стада молочної худоби. Тех- 
нологія виробництва і переробки продукції тваринництва. Біла Церква. 2010. Вип. 3 (72). С. 180-182.

6. Контэ А. Ф., Ермилов А. Н., Янчуков И. Н., Сермягин А. А. Параметры генетической взаимосвязи недостатков экстерьера с оценкой типа телосложения голштинизированных коров черно-пестрой породы. Генетика и разведение животных. 2018. №3. С. 32-38.

7. Кочук-Ященко О. А. Особливості екстер'єрного типу та молочної продуктивності корів-первісток української чорнорябої молочної породи за різних варіантів підбору. Вісник Сумського національного аграрного університету. Серія : Тваринництво. 2017. Вип. 5(1). С. 90-96.

8. Ладика В. І. Формування бажаного типу будови тіла швіцької худоби німецької селекції у процесі адаптації до умов Лісостепу України. Проблеми зооінженерії та ветеринарної медицини: Зб. наук. праць ХЗВІ. Харків. 1998. Вип. 4. Т. 1. С. 75 78.

9. Ладика В. І., Хмельничий Л. М., Салогуб А. М. Сполучна мінливість статей екстер'єру корів з молочною продуктивністю. Збірник наукових праць Білоцерківського НАУ Технологія виробництва і переробки продукції тваринництва. Біла Церква. 2010. Вип. 3 (72). С. 9-11.

10. Ладика В. І., Хмельничий Л. М., Шевченко А. П. Лінійна оцінка бугаїв-плідників голштинської та української чорнорябої молочної порід за екстер'єрним типом їхніх дочок. Вісник Сумського національного аграрного університету. Серія «Тваринництво». 2015. Вип. 2 (27). С. 3-8.

11. Ладика В. І., Хмельничий Л. М., Буркат В. П., Рубан С. Ю. Реєстрація ICAR. Довідник. Суми: Сумський національний аграрний університет, 2010. 457 c.

12. Лэсли Дж. Ф. Генетические основы селекции сельскохозяйственных животных. М. : Колос, 1982. 391 с.

13. Меркурьева Е. К. Биометрия в селекции и генетике сельскохозяйственных животных. М. : Колос, 1970. 423 с.

14. Пелехатий М. С., Шуляр А. Л. Порівняння новостворених молочних порід за екстер'єром і конституцією. Науковий вісник ЛНУВМБТ імені С.3. Ґжицького Том 12 № 3(45) Частина 3, 2010. С. 79-93.

15. Полупан, Ю. П. Оцінка бугаїв за типом дочок. Вісник аграрної науки. 2000. № 5. С. 45-49.

16. Полупан, Ю. П. Суб'єктивні акценти з деяких питань основ селекції та породоутворення. Розведення і генетика тварин. К.: Аграрна наука. 2007. Вип.41. С. 194-208.

17. Салогуб А. М., Хмельничий Л. М. Особливості успадковуваності та сполучної мінливості ознак екстер'єру корів української червоно-рябої молочної породи. Збірник наукових праць Вінницького НАУ. Серія: Сільськогосподарські науки. Вінниця. 2011. Вип. 8 (48). С. 59-62.

18. Тягунов Р. С., Гридин В. Ф. Оценка экстерьера коров голштинской породы различной селекции. Аграрный вестник Урала. 2012. № 2 (94), С. 22-23.

19. Хмельничий Л. Бажаний тип корів української червоно-рябої молочної породи. Тваринництво України. 2003. № 1.

20. Хмельничий Л. М. Екстер'єрний тип та продуктивність корів української чорно-рябої молочної породи, Науковотехнічний бюлетень Інституту тваринництва УААН. Харків. 2003. №. 84. С. 142-146.

21. Хмельничий Л. М. Лінійна класифікація молочної худоби в Україні: методологічні аспекти. Тваринництво України. 2013. № 1-2. С. 31-33.

22. Хмельничий Л. М. Порівняльна характеристика корів-первісток української чорно-рябої молочної та голштинської порід за екстер'єрним типом. Розведення і генетика тварин. К.: Аграрна наука. 2005. Вип. 39. С.216-222.

23. Хмельничий Л. М. Практичний досвід, стан та перспектива використання методики лінійної класифікації корів молочної худоби в Україні. Вісник Сумського національного аграрного університету. Серія «Тваринництво». 2013. Вип. 7 (23). С. 11-19.

24. Хмельничий Л. М. Реалізація спадковості бугаїв-плідників у співвідносній мінливості лінійної оцінки з молочною продуктивністю корів у віковій динаміці лактацій. Розведення і генетика тварин. К.: Аграрна наука. 2009. Вип. 43. С. $329-339$.

25. Хмельничий Л. М., Вечёрка В. В. Реализация наследственности быков-производителей в корреляционной изменчивости показателей линейной оценки с молочной продуктивностью коров в динамике лактаций. Генетика и разведение животных: Санкт-Петербург, Пушкин, «ОО Рекламное бюро “АЗ”». 2014. № 3. С. 4-9.

26. Хмельничий Л. М., Вечорка В. В. Вікова мінливість кореляцій між надоєм та лінійною оцінкою типу корів-первісток українських чорно- та червоно-рябої молочних порід. Технологія виробництва і переробки продуктів тваринництва. Збірник наукових праць БНАУ. Біла Церква. 2014. № 1 (116). С. 84-87.

27. Хмельничий Л. М., Ладика В. І., Полупан Ю. П. , Салогуб А. М. Методика лінійної класиффікації корів молочних і молочно-м'ясних порід за типом. Суми: ВВП “Мрія-1" ТОВ, 2008. 28 с.

28. Хмельничий Л. М., Лобода В. П., Шевченко А. П. Фенотипова та сполучена мінливість лінійних ознак екстер'єру корів молочних порід Сумщини. Розведення і генетика тварин. К.: 2015. Вип. 50. С. 103-111.

29. Хмельничий Л. М., Салогуб А. М. Особливості успадковуваності та сполучної мінливості ознак екстер'єру корів української червоно-рябої молочної породи. Збірник наукових праць Вінницького НАУ. Серія: Сільськогосподарські науки. Вінниця. 2011. Вип. 8 (48). С. 59-62.

30. Хмельничий Л. М., Салогуб А. М., Бондарчук В. М, Лобода В. П. Показники довічної продуктивності корів української червоно-рябої молочної породи залежно від методів підбору. Таврійський науковий вісник: Науковий журнал. Херсон: Грінь Д.С. 2015. Вип. 93. С. 191-196.

31. Хмельничий Л. М., Салогуб А. М., Вечорка В. В., Самохіна Є. А. Оцінка реалізації племінної цінності бугаївплідників на поголів'ї корів українських чорно- та червоно-рябої молочних порід. Вісник Сумського національного аграрного 
університету. Серія «Тваринництво». 2015. Вип. 6 (28). С. 13-19.

32. Хмельничий Л. М., Салогуб А. М., Хмельничий С. Л. Лінійна класифрікація корів сумського типу української чорнорябої молочної породи. Збірник наукових праць. Серія "Технологія виробництва і переробки продукції тваринництва". Кам'янець-Подільський. 2010. Вип. 18. С. 214-218.

33. Хмельничий, Л. Як добирати бажаний тип корів. Тваринництво України. 2006. № 5. С. 10-13.

34. Яранцева С. Б., Шишкина М. А. Оценка быков-производителей черно-пестрой породы по экстерьерному типу их дочерей. Достижения науки и техники АПК. 2010. №5. С. 60-61.

35. Atkins, G., Shannon, J., Muir, B. (2008). Using Conformational Anatomy to Identify Functionality \& Economics of Dairy Cows. WCDS Advances in Dairy Technology, 20: 279-295.

36. Berry, D.P., Buckley, R., Dillon, P., Evans, R.D., and Veerkamp, R.R. 2004. Genetic relationships among linear type traits, milk yield, body weight, fertility and somatic cell count in primiparous dairy cows. Irish J. Agr. Food Res.43:161-176. http://hdl.handle.net/11019/432

37. Campos R.V., Cobuci J.A., Kern E.L., Costa C.N., McManus C.M., and Campos R.V., 2015. Genetic Parameters for Linear Type Traits and Milk, Fat, and Protein Production in Holstein Cows in Brazil. Asian-Australas J Anim Sci. Apr; 28(4): $476-484$.

38. ICAR Guidelines for Conformation Recording of Dairy Cattle, Beef Cattle and Dairy Goats, 1/76. Section - 5, Conformation Recording, version June, 2018. [Електронний ресурс]. - Режим доступу: https://www.icar.org/Guidelines/05Conformation-Recording.pdf

39. Khmelnychyi L., Vechorka V., Salohub A., Khmelnychyi S., Rubtsov I. Heritability of traits of the type linear assessment and their genetic association with cow's milk yield of Ukrainian dairy breeds. Scientific Papers. Series "Management, Economic Engineering in Agriculture and Rural Development", 2020. Vol. 20 Issue 1. pp. 269-275.

40. Novotný L., Frelich J., Beran J., Zavadilová L. (2017): Генетичний взаємозв'язок між типовими ознаками, кількістю ініційованих очікувань та життєдіяльністю молока у чеської худоби Fleckvieh. Чех Дж. Аніма. Наук., 62: 501-510. https://doi.org/10.17221/60/2017-CJAS

41. Sawa A., Bogucki M., Krężel-Czopek S., Neja W. Relationship between Conformation Traits and Lifetime Production Efficiency of Cows. Veterinary Science. 2013. doi:10.1155/2013/124690.

42. Zink, V., L. Zavadilová, J. Lassen, M. Štípková, M. Vacek, L. Štolc. 2014. Analyses of genetic relationships between linear type traits, fat-to-protein ratio, milk production traits, and somatic cell count in first-parity Czech Holstein cows. Czech J. Anim. Sci., 59(12): 539-547.

\section{References:}

1. Antal, L., 2004. Razmyshleniya na temu: "byk - polovina stada" [Reflections on the theme: "bull is half of the herd"]. Molochnoe i myasnoe skotovodstvo, no. 1, pp. 16-20.

2. Basovskyy, M. Z., Rudyk, I. A. and Burkat, V. P., 1992. Vyroshchuvannya, otsinka i vykorystannya plidnykiv [Growth, estimation and use of sires]. Kyiv: Urozhay.

3. Efimova, L. V., Rostovtseva, N. M. and Koshurina, O. N., 2015. Lineynaya otsenka ekster'era docherey bykov krasnopestroy i golshtinskoy porod v Krasnoyarskom krae [Linear estimation of conformation bulls of daughters Red-and-White and Holstein breeds in the Krasnoyarsk Territory]. Mol. i myasnoe skotovodstvo, no. 8, pp. 20-22.

4. Karlikov, D. V. and Kleymenova, I. V., 1997. Nedostatki i poroki ekster'era cherno-pestrogo skota [Disadvantages and vices of Black-and-White cattle conformation]. Zootekhniya, no. 1, pp. 8-10.

5. Klopenko, N. I. and Rudyk, I. A., 2010. Vykorystannia selektsiino-henetychnykh parametriv u selektsii stada molochnoi khudoby [The use of selection and genetic parameters in the selection of dairy cattle]. Tekhnolohiia vyrobnytstva $i$ pererobky produktsii tvarynnytstva. Bila Tserkva, issue 3(72), pp. 180-182.

6. Konte, A. F., Ermilov, A. N., Yanchukov, I. N. and Sermyagin, A. A., 2018. Parametry geneticheskoy vzaimosvyazi nedostatkov ekster'era s otsenkoy tipa teloslozheniya golshtinizirovannykh korov cherno-pestroy porody [Parameters of genetic relationship of conformation shortcomings with body type assessment holsteinized cows of Black-and-White breed]. Genetika $i$ razvedenie zhivotnykh, no. 3, pp. 32-38.

7. Kochuk-Yashchenko, O. A., 2017. Osoblyvosti eksteriernoho typu ta molochnoi produktyvnosti koriv-pervistok ukrainskoi chorno-riaboi molochnoi porody za riznykh variantiv pidboru [Features of conformation type and milk productivity of cows firstborn Ukrainian Black-and-White dairy breed under different selection options]. Visnyk Sumskoho natsionalnoho ahrarnoho universytetu. Seriia : Tvarynnytstvo, issue 5(1), pp. 90-96.

8. Ladyka, V. I., 1998. Formuvannia bazhanoho typu budovy tila shvitskoi khudoby nimetskoi selektsii u protsesi adaptatsii do umov Lisostepu Ukrainy [Formation of the desired body type of Swedish cattle of German selection in the process of adaptation to the Forest-Steppe of Ukraine]. Problemy zooinzhenerii ta veterynarnoi medytsyny: Zb. nauk. prats KhZVI. Kharkiv, issue 4, pp. 75-78.

9. Ladyka, V. I., Khmelnychyi, L. M. and Salohub, A. M., 2010. Spoluchna minlyvist statei eksterieru koriv z molochnoiu produktyvnistiu [Correlative variability of the conformation type traits in cows with milk productivity]. Zbirnyk naukovykh prats Bilotserkivskoho NAU, issue 3(72), pp. 9-11.

10. Ladyka, V. I., Khmelnychyi, L. M. and Shevchenko, A. P., 2015. Liniina otsinka buhaiv-plidnykiv holshtynskoi ta ukrainskoi chorno-riaboi molochnoi porid za eksteriernym typom yikhnikh dochok [Linear estimation sires of Holstein and Ukrainian Black-and-White Dairy breeds for conformation type of their daughters]. Visnyk Sumskoho NAU, issue 2(27), pp. 3-8.

11. Ladyka, V. I., Khmelnychyi, L. M., Burkat, V. P. and Ruban, S. Yu., 2010. Reyestratsiya ICAR. Dovidnyk [ICAR Registra- 
tion: Reference book]. Sumy: Sumy National Agrarian University.

12. Lesli, Dzh. F., 1982. Geneticheskie osnovy selektsii sel'skokhozyaystvennykh zhivotnykh [Genetic basis of selective breeding farm animals]. Moskva: Kolos.

13. Merkur'eva, E. K., 1970. Biometriya v selektsii i genetike sel'skokhozyaystvennykh zhivotnykh [Biometrics in the selection and genetics of farm animals]. Moskva: Kolos.

14. Pelekhatyy, M. S. and Shulyar, A. L., 2010. Porivniannia novostvorenykh molochnykh porid za eksterierom i konstytutsiieiu [Comparison of newly created dairy breeds by conformation and constitution]. Nauk. visnyk LNUVM im. S. Z. Hzhytskoho. Lviv, no. 3(45), pp. 79-93.

15. Polupan, Yu. P., 2000. Otsinka buhaiv za typom dochok [Estimation of sires according to the type of daughters]. Visnyk ahrarnoi nauky, issue 5, pp. 45-49.

16. Polupan, Yu. P., 2007. Subiektyvni aktsenty z deiakykh pytan osnov selektsii ta porodoutvorennia [Subjective accents on some questions about genetic basis of selection and breed formation]. Rozvedennia i henetyka tvaryn, issue 41, pp. 194-208.

17. Salohub, A. M. and Khmelnychyi, L. M., 2011. Osoblyvosti uspadkovuvanosti ta spoluchnoi minlyvosti oznak eksterieru koriv ukrainskoi chervono-riaboi molochnoi porody [Features of heritability and correlative variability of the conformation traits of cows of Ukrainian Red-and-White dairy breed]. Collection of scientific works of Vinnitsa NAU. Series: Agricultural Sciences, issue 8, pp. 59-62.

18. Tyagunov, R. S. and Gridin, V. F., 2012. Otsenka ekster'era korov golshtinskoy porody razlichnoy selektsii [Assessment of Holstein cows conformation of various selection]. Agrarnyy vestnik Urala, no. 2(94), pp. 22-23.

19. Khmelnychyi, L. M., 2003. Bazhanyi typ koriv ukrainskoi chervono-riaboi molochnoi porody [Desired type of cows of Ukrainian Red-and-White dairy breed]. Tvarynnytstvo Ukrainy, no. 1, pp. 23-24.

20. Khmelnychyi, L. M., 2003. Eksteriernyi typ ta produktyvnist koriv ukrainskoi chorno-riaboi molochnoi porody [Conformation type and productivity of cows Ukrainian Black-and-White dairy breed]. Naukovo-tekhnichnyi biuleten Instytutu tvarynnytstva UAAN. Kharkiv, no. 84, pp. 142-146.

21. Khmelnychyi, L. M., 2013. Liniyna klasyfikatsiya molochnoyi khudoby $v$ Ukrayini : metodolohichni aspekty [Linear classification of dairy cattle in Ukraine : methodological aspects]. Tvarynnytstvo Ukrayiny, 1(2), pp. 31-33.

22. Khmelnychyi, L. M., 2005. Porivnialna kharakterystyka koriv-pervistok ukrainskoi chorno-riaboi molochnoi ta holshtynskoi porid za eksteriernym typom [Comparative characteristic cows firstborn of Ukrainian Black-and-White dairy and Holstein breeds by conformation type]. Rozvedennya i henetyka tvaryn, issue 39, pp. 216-222.

23. Khmelnychyi, L. M., 2013. Praktychnyy dosvid, stan ta perspektyva vykorystannya metodyky liniynoyi klasyfikatsiyi koriv molochnoyi khudoby v Ukrayini [Practical experience, status and prospects of using linear classification method of cows dairy cattle in Ukraine]. Visnyk Sums'koho natsional'noho ahrarnoho universytetu. Seriya "Tvarynnytstvo", issue 7(23), pp. 11-19.

24. Khmelnychyi, L. M., 2009. Realizatsiia spadkovosti buhaiv-plidnykiv u spivvidnosnii minlyvosti liniinoi otsinky z molochnoiu produktyvnistiu koriv u vikovii dynamitsi laktatsii [Implementation inheritance of sires in comparable variability of linear estimation with milk productivity of cows in lactations age dynamics]. Rozvedennia i henetyka tvaryn. K.: Ahrarna nauka, no. 43, pp. 329-339.

25. Khmel'nichiy, L. M. and Vecherka, V. V., 2014. Realizatsiya nasledstvennosti bykov-proizvoditeley v korrelyatsionnoy izmenchivosti pokazateley lineynoy otsenki s molochnoy produktivnost'yu korov $v$ dinamike laktatsiy [Realization of sires inheritance in correlation variability of linear assessment indicators with milk productivity of cows in dynamics of lactations]. Genetika $i$ razvedenie zhivotnykh: Sankt-Peterburg, Pushkin, «OO Reklamnoe byuro "AZ”», no. 3, pp. 4-9.

26. Khmelnychyi, L. M. and Vechorka, V. V., 2014. Vikova minlyvist koreliatsii mizh nadoiem ta liniinoiu otsinkoiu typu korivpervistok ukrainskykh chorno- ta chervono-riaboi molochnykh porid [Age variability of correlations between milk yield and linear assessment of type cows firstborn of Ukrainian Black- Red-and-White dairy breeds]. Tekhnolohiia vyrobnytstva i pererobky produktiv tvarynnytstva. Zbirnyk naukovykh prats BNAU. Bila Tserkva, no. 1(116), pp. 84-87.

27. Khmelnychyi, L. M., Ladyka, V. I., Polupan, Yu. P. and Salohub, A. M., 2008. Metodyka liniinoi klasyfikatsii koriv molochnykh i molochno-miasnykh porid za typom [Method of linear classification cows of dairy and dairy-beef breeds by type]. Sumy: VVP "Mriia-1" TOV.

28. Khmelnychyi, L. M., Loboda, V. P. and Shevchenko, A. P., 2015. Fenotypova ta spoluchena minlyvist liniinykh oznak eksterieru koriv molochnykh porid Sumshchyny [Phenotypic and correlated variability of conformation linear traits of dairy cows in Sumy region]. Rozvedennia i henetyka tvaryn, issue 50, pp. 103-111.

29. Khmelnychyi, L. M. and Salohub, A. M., 2011. Osoblyvosti uspadkovuvanosti ta spoluchnoi minlyvosti oznak eksterieru koriv ukrainskoi chervono-riaboi molochnoi porody [Features heritability and connective variability of conformation traits cows Ukrainian Red-and-White dairy breed]. Zbirnyk naukovykh prats Vinnytskoho NAU. Seriia: Silskohospodarski nauky. Vinnytsia, issue 8(48), pp. 59-62.

30. Khmelnychyi, L. M., Salohub, A. M., Bondarchuk, V. M. and Loboda, V. P., 2015. Pokaznyky dovichnoi produktyvnosti koriv ukrainskoi chervono-riaboi molochnoi porody zalezhno vid metodiv pidboru [Indicators of lifetime productivity of cows Ukrainian Red-and-White dairy breed depending on selection methods]. Tavriiskyi naukovyi visnyk: Naukovyi zhurnal. Kherson, issue 93, pp. 191-196.

31. Khmelnychyi, L. M., Salohub, A. M., Vechorka, V. V. and Samokhina, Ye. A., 2015. Otsinka realizatsii pleminnoi tsinnosti buhaiv-plidnykiv na poholivi koriv ukrainskykh chorno- ta chervono-riaboi molochnykh porid [Assessment of sires breeding value realization on the number of cows Ukrainian Black- and Red-and-White dairy breeds]. Visnyk Sums'koho natsional'noho ahrarnoho universytetu. Seriya "Tvarynnytstvo", issue 6(28), pp. 13-19. 
32. Khmelnychyi, L. M., Salohub, A. M. and Khmelnychyi, S. L., 2010. Liniina klasyfikatsiia koriv sumskoho typu ukrainskoi chorno-riaboi molochnoi porody [Linear classification of Sumy-type cows of Ukrainian Black-and-White dairy breed]. Zbirnyk naukovykh prats. Seriia "Tekhnolohiia vyrobnytstva i pererobky produktsii tvarynnytstva". Kamianets-Podilskyi, issue 18, pp. 214218.

33. Khmelnychyi, L. M., 2006. Yak dobyraty bazhanyi typ koriv [How to choose the desired type of cows]. Tvarynnytstvo Ukrainy, no. 5, pp. 10-13.

34. Yarantseva, S. B. and Shishkina, M. A., 2010. Otsenka bykov-proizvoditeley cherno-pestroy porody po ekster'ernomu tipu ikh docherey [Assessment of Black-and-White sires by the conformation type of their daughters]. Dostizheniya nauki $i$ tekhniki APK, no. 5, pp. 60-61.

35. Atkins, G., Shannon, J. and Muir, B., 2008. Using conformational anatomy to identify functionality \& economics of dairy cows. WCDS Advances in Dairy Technology, 20:279-295.

36. Berry, D. P., Buckley, R., Dillon, P., Evans, R. D. and Veerkamp, R. R., 2004. Genetic relationships among linear type traits, milk yield, body weight, fertility and somatic cell count in primiparous dairy cows. Irish J. Agr. Food Res. 43:161-176. http://hdl.handle.net/11019/432

37. Campos, R. V., Cobuci, J. A., Kern, E. L., Costa, C. N., McManus, C. M. and Campos, R. V., 2015. Genetic parameters for linear type traits and milk, fat, and protein production in Holstein cows in Brazil. Asian-Australas J Anim Sci., 28(4): $476-484$.

38. ICAR Guidelines for Conformation Recording of Dairy Cattle, Beef Cattle and Dairy Goats, 1/76. Section - 5, Conformation Recording, version June, 2018. [Електронний ресурс]. - Режим доступу: https://www.icar.org/Guidelines/05Conformation-Recording.pdf

39. Khmelnychyi, L., Vechorka, V., Salohub, A., Khmelnychyi, S. and Rubtsov, I., 2020. Heritability of traits of the type linear assessment and their genetic association with cow's milk yield of Ukrainian dairy breeds. Scientific papers. Series "management, economic engineering in agriculture and rural development", issue 1, pp. 269-275.

40. Novotný, L., Frelich, J., Beran, J. and Zavadilová, L., 2017.: Генетичний взаємозв'язок між типовими ознаками, кількістю ініційованих очікувань та життєдіяльністю молока у чеської худоби Fleckvieh. Чех Дж. Аніма. Наук., 62:501-510. https://doi.org/10.17221/60/2017-CJAS

41. Sawa, A., Bogucki, M., Krężel-Czopek, S. and Neja, W., 2013. Relationship between conformation traits and lifetime production efficiency of cows. Veterinary Science. doi:10.1155/2013/124690.

42. Zink, V., L., Zavadilová, J., Lassen, M., Štípková, M., Vacek, L. and Štolc., 2014. Analyses of genetic relationships between linear type traits, fat-to-protein ratio, milk production traits, and somatic cell count in first-parity Czech Holstein cows. Czech J. Anim. Sci., 59(12):539-547.

\section{Khmelnychyi Leontii Mykhailovych, Doctor of Agricultural Sciences, Professor \\ Karpenko Bogdan Mykolaiovych, graduate student, \\ Sumy National Agrarian University (Sumy, Ukraine)}

The effectiveness of sires use, assessed by conformation type of their daughters, in the herd for breeding dairy cat-

Research sires of Holstein breed was carried out for conformation type of their daughters in the conditions of particular farm. The modern method of linear classification recommended by the international organization ICAR was used for assessment. Cows at the age of the first lactation were evaluated for 2-4 months after calving on a 100-score and 9-score scale. Studies conducted in the herd of PE "Burynske" Pidlisnivskoyi branch Sumy region. Comparative analysis of sires made it possible to identify among them conformation type improvers by linear assessment of their daughters. According to results of sires estimation by 100-score system of linear classification, the highest scores for development of group traits and final assessment were sires McDaddy 138438344 (83.584.6 and 84.2 score) and J. Rueben 137936344 (83.4- 84.4 and 83.7 score). In general, daughters of all estimated Holstein sires inherited good development of all conformation body parts, as evidenced by estimates of descriptive traits, level of which exceeded average value of their development in the breed. The exception concerned only front and rear teats position and pelvic limbs angle in daughters of certain sires. Productivity daughters estimated by linear classification of sires for highest yield per lactation, depending on the assessment level of body parts that characterize dairy type expression ( $r=0.244-0.424)$, body development $(r=0.286-0.386)$, udder $(r=0.312-0.461)$ and final score $(r=0.318-0.475)$ with reliability $P<0.05-0.001$. With varying degrees of reliability, installed positive correlation between milk yield and descriptive traits: height in rump ( $r=0.124-0.303)$, body depth $(r=0.226-0.324)$, angularity $(r=0.277-0.395)$, rump width $(r=0.214-0.287)$, pelvic limbs posture $(r=0.217-0.286)$, front udder parts attachment $(r=0.244$ $0.384)$ and negative - between body condition and milk yield $(r=-0.118 \ldots-0.322)$. In the process of improving the herd for breeding Holstein breed on the conformation, it is necessary to actively use sires, estimated by the method of linear classification of their daughters, which will ensure the effectiveness of herd selection by type and dairy productivity.

Key words: Holstein breed, linear type estimation, correlation, conformation body parts

Дата надходження до редакції: 13.11.2020 р. 